\title{
How to Control Subannular Hemorrhage during Aortic Root Enlarging Procedures
}

\author{
Abdallah K. Alameddine, MD ${ }^{1} \quad$ Brian Binnall, PA-C ${ }^{1} \quad$ Frederick T. Conlin, MD ${ }^{2} \quad$ Khaled O. Alameddine, $\mathrm{MS}^{3}$ \\ ${ }^{1}$ Division of Cardiac Surgery, Baystate Medical Center, Springfield, \\ Massachusetts \\ ${ }^{2}$ Division of Anesthesiology, Baystate Medical Center, Springfield, \\ Massachusetts \\ ${ }^{3}$ Department of Internal Medicine, Swedish Covenant Hospital, \\ Chicago, Illinois \\ Address for correspondence Abdallah K. Alameddine, MD, Baystate \\ Medical Center, 759 Chestnut Street, Springfield, MA 01107 \\ (e-mail: akalameddine@gmail.com). \\ AORTA 2018;6:120-123.
Abstract
Keywords
- aortic stenosis
- small aortic root
- destroyed aortic annulus
- subannular patch bleeding
- aortoventricular rupture \\ We describe an effective suture technique to control the persistent subannular \\ bleeding at the aortoventricular curtain in four patients with aortic stenosis and small \\ annulus who underwent aortic root enlargement and patch reconstruction. This \\ technique approximates the left atrial roof to the aortic root without the need for \\ re-replacement of the aortic prosthesis or revision of the patch. Reintervention for \\ aortic root, valve, or the residual aorta was not required.
}

\section{Introduction}

Ongoing subannular bleeding ( $\mathrm{SAB}$ ) following aortic root enlargement can be life threatening and justifies an aggressive surgical posture. In the case of aortic root enlarging procedures with a patch repair (Nicks or Manougian incisions in patients with a small aortic annulus), ${ }^{1,2}$ intraoperative bleeding seeping through the anchoring lower end of the patch repair is most likely to occur following extensive annular debridement, excessive suture tension for tissue approximation (resulting in disruption of friable tissue), inaccessible exposure due to the small aortic root, or implantation of an oversized prosthesis. The bleeding site at the aortoventricular curtain cannot be visualized due to the narrow anatomic space as it is subannular under the prosthetic valve sewing ring (whether it is mechanical or bioprosthetic) $)^{3}$ and risks becoming life threatening.

Various approaches to hemorrhage control at this site have been attempted. One traditional option entails redoing the entire procedure and replacing the old prosthesis and the patch, which can significantly prolong ischemic and bypass time. The other option, as we previously reported, is a "U" stitch repair to control bleeding from a damaged intertrigonal area (aortic-mitral curtain) during tissue aortic valve replacement (AVR) by reinforcing the subannular tissue from within the aorta without removing the aortic bioprosthesis. ${ }^{3}$ However, this technique cannot be used when dealing with a mechanical aortic prosthesis.

In the current approach, the left atrial dome tissue is approximated to the neighboring greater curvature of the aorta with the goal being complete obliteration of the subannular aortoventricular bleeding site. This method has been used successfully in a small clinical series of four patients without the need for removal of the old prosthesis or revision of the patch.

\section{Patients and Methods}

\section{Patient Profiles and Clinical Experience}

Between December 2014 and April 2016, four patients underwent AVR with patch enlargement procedures for small aortic root complicated by intraoperative $S A B$ and received

September 12, 2017

accepted after revision

November 5, 2018
DOI https://doi.org/

10.1055/s-0039-1683387. ISSN 2325-4637.
Copyright $\odot 2018$ by Thieme Medical

Publishers, Inc., 333 Seventh Avenue, New York, NY 10001, USA.

Tel: +1(212) 584-4662.
License terms

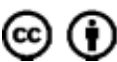


Table 1 Demographic and clinical patient characteristics and outcomes data

\begin{tabular}{|c|c|c|c|c|}
\hline Variables & Case 1 & Case 2 & Case 3 & Case 4 \\
\hline Age & 78 & 77 & 59 & 77 \\
\hline Sex & $\mathrm{F}$ & $M$ & $\mathrm{~F}$ & M \\
\hline Primary diagnosis & Aortic stenosis & Aortic and mitral stenosis & $\begin{array}{l}\text { MSSA infective } \\
\text { endocarditis with } \\
\text { root abscess }\end{array}$ & $\begin{array}{l}\text { Aortic stenosis } \\
5.5 \mathrm{~cm} \text { Ascending aortic } \\
\text { aneurysm }\end{array}$ \\
\hline $\begin{array}{l}\text { Operation } \\
\text { performed }\end{array}$ & $\begin{array}{l}\text { AVR (\#21 St. Jude } \\
\text { Trifecta) Aortic root } \\
\text { enlargement with } \\
\text { Hemashield patch }\end{array}$ & $\begin{array}{l}\text { Redo AVR (\#19 St. Jude } \\
\text { Regent) MVR (\#19 Magna } \\
\text { Ease) and enlargement } \\
\text { with Hemashield patch }\end{array}$ & $\begin{array}{l}\text { Redo AVR (\#19 St Jude } \\
\text { Regent), bovine patch } \\
\text { reconstruction, LVOT } \\
\text { with aortic annular } \\
\text { enlargement }\end{array}$ & $\begin{array}{l}\text { AVR (\#29 Model 2700), } \\
\text { Ascending aortic } \\
\text { replacement (\#30 } \\
\text { Hemashield tube graft } \\
\text { and patch) } \\
\text { Left atrial Cryo-Maze, left } \\
\text { atrial appendage ligation }\end{array}$ \\
\hline $\begin{array}{l}\text { 24-hour chest } \\
\text { tube output }\end{array}$ & $360 \mathrm{~mL}$ & $430 \mathrm{~mL}$ & $75 \mathrm{~mL}$ & $320 \mathrm{~mL}$ \\
\hline $\begin{array}{l}\text { Re-exploration } \\
\text { for bleeding }\end{array}$ & No & No & No & No \\
\hline Outcome & $\begin{array}{l}\text { Alive and well after } \\
14 \text { months follow-up }\end{array}$ & $\begin{array}{l}\text { Alive with liver cirrhosis } \\
\text { after } 28 \text { months follow- } \\
\text { up }\end{array}$ & $\begin{array}{l}\text { Died POD \#23, MSOF } \\
\text { secondary to right heart } \\
\text { failure. }\end{array}$ & $\begin{array}{l}\text { Alive with metastatic } \\
\text { pancreatic cancer after } \\
10 \text { months follow-up }\end{array}$ \\
\hline $\begin{array}{l}\text { Postop aortic } \\
\text { gradient }(\mathrm{mm} \mathrm{Hg})\end{array}$ & 15 & 20 & 12 & 6 \\
\hline $\begin{array}{l}\text { Cross clamp time/ } \\
\text { CPB time (min) }\end{array}$ & $107 / 149$ & $341 / 424$ & $203 / 226$ & $190 / 200$ \\
\hline
\end{tabular}

Abbreviations: AVR, aortic valve replacement; CPB, cardiopulmonary bypass; LVOT, left ventricular outflow tract; MSOF, multiple system organ failure; MSSA, methicillin-sensitive Staphylococcus aureus; POD, postoperative day.

were retrospectively reviewed. Waiver for individual consent was granted by our Institutional Review Board. The demographic and clinical patient characteristics as well as outcomes data are reported in -Table 1. The ages of the patients were between 59 and 78 years. Before the operation, all patients were investigated by echocardiography and cardiac catheterization. Postoperatively, patients were evaluated by clinical examination and echocardiography.

\section{Surgical Technique}

This technique might be applicable in all types of SAB including modified Bentall procedures. In AVR, a median sternotomy and cardiopulmonary bypass (CPB) are used in a standard fashion. Usually the bleeding is noticed immediately when coming off CPB originating from below the valve. The following repair technique is used preferably with reinstating $\mathrm{CPB}$ to improve visualization and to prevent further injury to the aorta or left atrial dome.

Full-thickness bites are made through the left atrial dome myocardial tissue and are passed through to the neighboring aortic root tissue, closing the gap by using pledgeted doublearmed renal artery bypass (RB) 1 or small half circle (SH) 4-0 polypropylene sutures. It is also possible to use 2-0 Ethibond (Ethicon, Sommerville, NJ) polyester sutures. The bites on the aortic wall should be periadventitial (partial thickness) to reduce the theoretical risk of transmural aortic injury with subsequent pseudoaneurysm formation. The other arm of the suture is brought back through the dome and tied to the first suture arm. Teflon felt pads are used for reinforcement of the suture line and to avoid cutting through and disrupting this thinned area. Knot tying is done snug, just enough to exclude the space by attaching (imbricating) the left atrial dome tissue superiorly against the exposed outer aortic wall caudally. Further sutures may be required by carrying the suture line along the left side of the aorta and going over the upper adventitial edge of the right pulmonary artery and sealing off the right entrance of the transverse sinus; any potential exit for the bleeding is thus sealed. The additional sutures are spaced $2 \mathrm{~mm}$ apart using the prior meticulously placed suture to retract, as one goes around the suture line closure from right to left. The final result is illustrated in the -Fig. 1, where the bleeding trajectory-originating from the lower end of the patch-is sealed off superiorly. During placement of the sutures, CPB flow is decreased but keeping up with the left ventricular vent to avoid sucking air from the suture needle holes in the left atrial dome.

\section{Results}

Mean age of patients was 68 years and two were female. A modified Manouguian technique was performed without entering into the left atrium. A limited incision over the anterior mitral leaflet was done for a distance $<4 \mathrm{~mm}$, and the enlargement was achieved by extending the aortotomy posteriorly into the fibrous tissue between the noncoronary cusp and the left coronary cusp and onto the subaortic curtain. One patient had the aortic valve replaced with a mechanical prosthesis and three with a bioprosthetic valve. The choice of patch was the surgeon's preference. Concomitant procedures included mitral valve replacement in one patient, and 


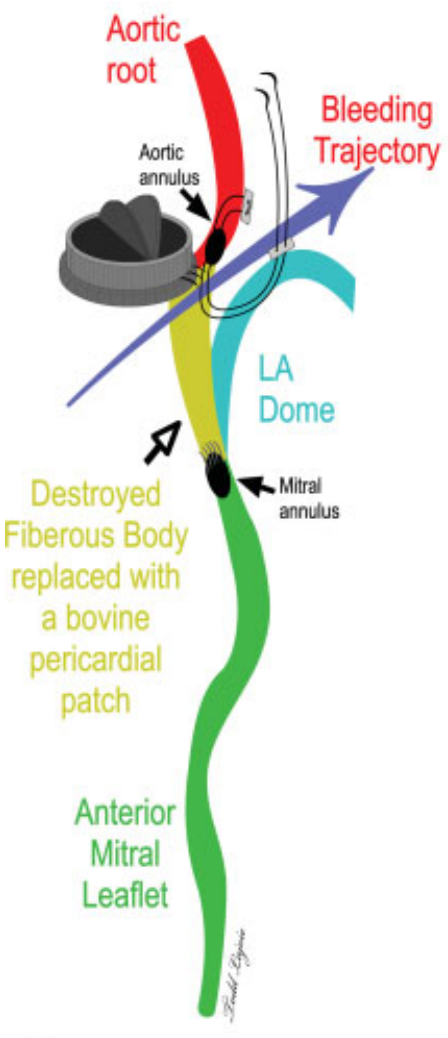

A

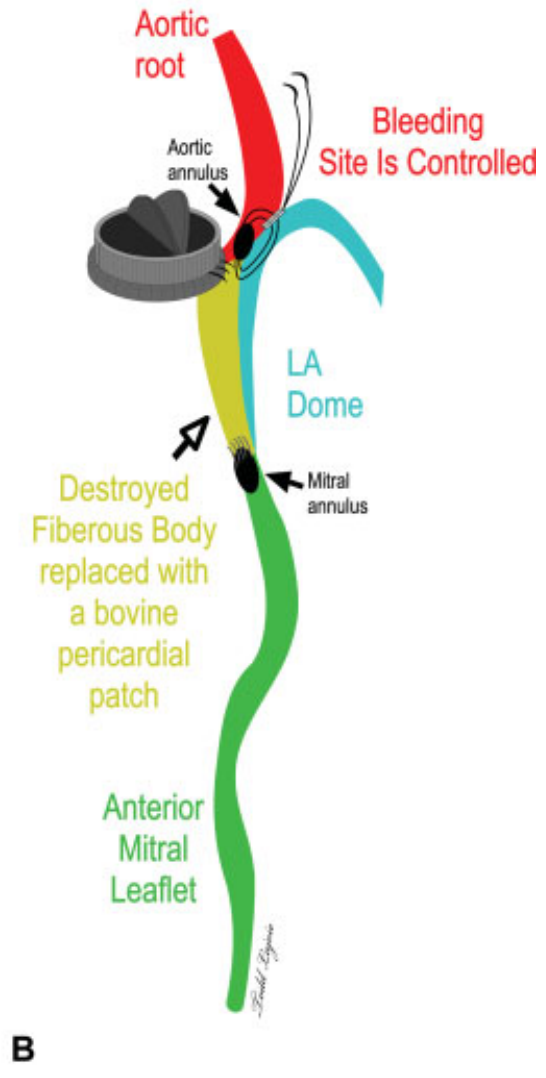

Fig. 1 Illustration of the surgical repair: (A) before: the bleeding in such a situation happens at the lowermost point of the patch and (B) after placement of the stitch (es) above the bleeding site. LA, left atrium.

ascending aortic aneurysm repair and a CryoMaze procedure in another. Redo AVR was performed in two patients, in one of whom Staphylococcus aureus endocarditis was present. Two patients received a mechanical prosthesis (St. Jude Medical, St. Paul, MN) and two patients received bioprosthesis (Edwards Lifesciences, Irvine, CA). There was one hospital death from multisystem organ failure; the remaining three patients were well at last follow-up visit, and there has been no late death. All of the patients underwent transthoracic echocardiography with a mean postoperative interval of 16 months, and none required reintervention for aortic root, the valve, or for the residual aorta.

\section{Discussion}

There is naturally a weakened and thinned out area where the mitral valve and the subaortic curtain meet between the fibrous trigones that separate it from the outside. ${ }^{4}$ Intraoperative $S A B$ from disruption of this friable area, following AVR with patch enlargement of the root, is a major and severe complication with an unknown incidence.

In a retrospective review of 2,366 cases of AVR performed at the Mayo Clinic over a 9-year period, $10.5 \%$ of all AVRs required a posterior aortic root enlargement. In the root enlargement group, a $4.8 \%$ rate of reoperations for bleeding occurred (unspecified bleeding site), and the reported raw operative mortality was $5.6 \% .^{5}$

\section{Prevention of Bleeding}

Our recommendation is not to disrupt the thin and delicate layer of loose tissue veil that attaches the left atrial dome to the aortic root during the dissection in preparation for the enlargement of the aortic root. This step of the operation should be done meticulously using a Kittner dissector or the tips of scissors to free just enough of the aortic root from its surrounding tissues staying on the left atrial wall. The extra time spent on this step of the operation will pay great dividends by avoiding pseudoaneurysm formation in the aortic root, as well as bleeding into and separation of the left atrial wall. ${ }^{6,7}$

We reserve the current approach for cases in which the tear or dehiscence is localized or confined to a single area. It can also be used as a prophylaxis before the aortic crossclamp is released if the repair was thought to be untenable. The main advantages are retaining the prosthesis in place and avoiding longer ischemic and bypass time. If bleeding recurs after the stitch is placed, then that situation is addressed by redoing the entire procedure.

In conclusion, the current extra-aortic stitch is the suggested management option in selected individual patients with unexpected SAB when reclamping the aorta is undesirable. This choice is a potentially very useful technique, and it offers a less invasive and more facile technique given the alternative choice of redoing the entire valve replacement procedure with direct access via an intra-aortic approach and recross-clamping the aorta. Further studies with a larger 
numbers of patients and longer follow-up are required to validate this approach.

Funding

None.

\section{Conflict of Interest}

The authors declare no conflict of interest related to this article.

\section{References}

1 Nicks R, Cartmill T, Bernstein L. Hypoplasia of the aortic root. The problem of aortic valve replacement. Thorax 1970;25(03): 339-346

2 Manouguian S, Seybold-Epting W. Patch enlargement of the aortic valve ring by extending the aortic incision into the anterior mitral leaflet. New operative technique. J Thorac Cardiovasc Surg 1979; 78(03):402-412

3 Alameddine AK, Alimov VK, Flack JE. Repair of intervalvular fibrous body rupture during aortic valve replacement. J Card Surg 2011;26:372-374

4 Yacoub M, Onuzo O, Riedel B, Radley-Smith R. Mobilization of the left and right fibrous trigones for relief of severe left ventricular outflow obstruction. J Thorac Cardiovasc Surg 1999;117(01): 126-132, discussion 32-33

5 Dhareshwar J, Sundt TM III, Dearani JA, Schaff HV, Cook DJ, Orszulak TA. Aortic root enlargement: what are the operative risks? J Thorac Cardiovasc Surg 2007;134(04):916-924

6 Morisaki A, Kato Y, Motoki M, Takahashi Y, Nishimura S, Shibata T. Rupture of equine pericardial aortic-root patch after aortic valve replacement with aortic annulus enlargement: a case report. J Cardiothorac Surg 2014;9:109

7 Fukuhara S, Dimitrova KR, Geller CM, Hoffman DM, Ko W, Tranbaugh RF. Left atrial dissection: etiology and treatment. Ann Thorac Surg 2013;95(05):1557-1562 